\title{
Changes in paddy field management in Sindang Hamlet, Rancakalong Village, Sumedang District, West Java, Indonesia
}

\author{
RAHMI AULIA HIDAYAT ${ }^{1, \bullet}$, RUHYAT PARTASASMITA ${ }^{2, \bullet \bullet}$, JOHAN ISKANDAR ${ }^{2}$, BUDI GUNAWAN ${ }^{3}$ \\ ${ }^{1}$ Environmental Science Graduate Program, Graduate School, Universitas Padjadjaran. Jl. Sekeloa Selatan I, Bandung 40134, West Java, Indonesia. \\ Tel.: +62-22-2508871, Fax.: +62-22-2504982, ^email: rahmiauliahidayat@gmail.com \\ ${ }^{2}$ Department of Biology, Faculty of Mathematics and Natural Sciences, Universitas Padjajaran. J1. Raya Bandung-Sumedang Km 21 Jatinangor, \\ Sumedang 45363, West Java, Indonesia. Tel.: +62-22-7797712, "email: rp2010rikkyo@gmail.com; ruhyat.partasasmita@unpad.ac.id \\ ${ }^{3}$ Department of Anthropology, Faculty of Social and Political Science, Universitas Padjadjaran. J1. Raya Bandung-Sumedang Km 21 Jatinangor, \\ Sumedang 45363, West Java, Indonesia
}

Manuscript: 17 October 2019. Revision accepted: 8 December 2019.

\begin{abstract}
Hidayat R.A, Partasasmita R, Iskandar J, Gunawan B. 2020. Changes in paddy field management in Sindang Hamlet, Rancakalong Village, Sumedang District, West Java, Indonesia. Biodiversitas 21: 98-105. Farmers have traditional ecological knowledge related to the management of their fields, including knowledge of climate, soil types, soil fertility, various plants and animals, plant pests and irrigation. This knowledge is based on customs, beliefs and cosmos. Over time, government policies in agriculture such as the green revolution were implemented with the aim of increasing productivity of rice in wet-rice field farming. This initiated a change in the community's farming system from subsistence farming to commercial farming. Not to mention the existence of climate change that requires people to adapt. This change has an impact on ecological, economic and social aspects which are interesting to study. This study conducted in Sindang Hamlet, Rancakalong Village, Sumedang District, West Java, which is known to have local rice cultivars and still practices rituals related to rice management. This study aims to analyze the changes in paddy management system in Sindang Hamlet due to green revolution and climate change, using qualitative data collection methods such as semi-structured interviews (deep interviews) with competent locals and participatory observations. Result of study showed that presently there are 3 groups of farmers in Sindang Hamlet, farmers who plant only local rice cultivars, farmers who plant only superior rice cultivars, and farmers who plant both local rice and superior rice cultivars in their land. Most farmers in Sindang Hamlet planted local rice but the diversity of local rice has decreased leaving only six cultivars, namely rayot, mesir, omas, torondol, mataram and randa kaya. There are still farmers in Sindang Hamlet who practice traditional farming, but many are starting to use modern tools and synthetic chemicals. The rice field management ritual called ngalaksa is still observed by the community, although there are some changes over time. The changes in rice field management have a negative impact on the local environment, economy and social aspects.
\end{abstract}

Keywords: Change, paddy management, Rancakalong

\section{INTRODUCTION}

According to Berkes (2008), Traditional Ecological Knowledge (TEK) is a collection of knowledge, practices and beliefs about the relationship between living things (including humans) with one another and with the environment, which develops through the process of adaptation and is passed down from generation to generation by cultural transmission. Traditional ecological knowledge is dynamic, built on experiences, and adaptive to change. Traditional ecological knowledge possessed by farmers includes knowledge about climate, soil types, soil fertility, diverse plants and animals, plant pests, and irrigation (Iskandar 2012). This knowledge will affect the practice in daily life, for farmers certainly in the practice of agricultural management.

Traditional farmers, before the green revolution, were having substantial knowledge about rice cultivars and cropping patterns. This is not surprising because farmers had long managed native rice cultivars in their local environments, such as rain-fed rice fields, irrigated rice fields and tidal rice fields. Besides being rich in local knowledge, traditional farmers were very careful in managing agriculture so that environmental damage was avoided and the balance of agricultural ecosystems was maintained (Simatupang 2017; Iskandar and Iskandar 2017; Partasasmita et al. 2019). Farmers in rural West Java were practicing agriculture, in the past, based on traditional ecological knowledge (corpus), beliefs, and the cosmos (Mustapa 1996; Toledo 2002; Iskandar, 2016).

The cycle of planting rice in many areas in West Java was generally determined by rainfall patterns. For example, they planted rice twice a year; once in the dry season and next in the rainy season. Growing rice during the rainy season is called primary cultivation (main planting season), whereas during the dry season it is considered a "morekat planting season" (Sundanese). Wet rice fields are usually planted with various native rice cultivars, both sticky and non-sticky rice. Rice cultivars are planted in separate paddy fields based on different local environments (Iskandar and Iskandar 2018).

As the population increased, the management of traditional agriculture changed. This required an increase in food production to meet the needs of the community. In order to increase paddy production, the Indonesian government introduced the Green Revolution program in 
the late 1960s. The program included introducing several new high yielding rice varieties ( HYVs), such as IR5 and IR8. The implementation timing of the green revolution program in Java, especially in West Java, was different. The Green Revolution was implemented in the northern coast of West Java (Indramayu) in the early 1970s (Maarif 2008). Meanwhile, the influence of the green revolution in the highlands of West Java such as Sumedang began to be felt in 1980s (Warsiti 2009).

The green revolution program was the government's solution to overcome food difficulties. However, this program caused many changes that have both positive and negative impacts on various aspects. The Green Revolution Program provided benefits, such as increasing rice production (Iskandar and Iskandar 2018). But this program also caused various losses. Ecologically, the important losses caused were extinction of various local rice cultivars in several regions (Iskandar and Ellen 1999; Soemarwoto 2007; Warsiti 2009), water and soil pollution, decreased soil fertility (Fox 1991; Lansing 1991), and explosion of pests of brown plant hopper (wereng batang coklat) which was a consequence of the intensive use of pesticides (Winarto 2016).

Economically, the green revolution has changed the system of rice farming which was originally used inputs from within (the use of biological fertilizers and pesticides) and independent traditional irrigation arrangements, to be highly dependent on external inputs and modern technology (Iskandar and Iskandar 2011; Amelia et al. 2018). Besides that, there also social impacts such as increasing gap between poor farmers and rich farmers (Iskandar 2001), erosion of farmers' knowledge of traditional agricultural management (Winarto 1998), and shifts in value systems and loosening of social relations in agricultural practices (Lauer 2003).

In addition to the influence of the green revolution which was a government policy, an uncertain climate also causing changes in rice management practices. Farmers in rural areas are known to have knowledge related to traditional dating about the management of their agricultural land (Iskandar and Iskandar 2016). This is the result of observation (information's input) of natural signs such as animals and plants in determining the planting or harvesting time. The occurrence of climate change makes these natural signs no longer accurate. Community knowledge related to the traditional calendar is getting abandoned. The communities are also making several changes to their land management practices as adaptations to climate change.

The green revolution and climate change have affected agricultural practices by traditional communities in various regions. Several studies aimed at analyzing such changes, especially in rice management systems, have shown mixed results. A study by Iskandar and Ellen in Baduy (1999) showed no drastic changes. On the contrary, rice farming practices in Karangwangi Village showed significant changes (Partasasmita et al. 2019). Rice farming in Kuta Village shows change with regard to management practices, while certain rituals related to farm management are still maintained (Kadarisno 2019).

An earlier study related to the management of paddy fields in Sindang hamlet, Rancakalong Village by Warsiti (2009), indicated a decrease in local rice cultivars when compared to the previous years. The present study has been undertaken to further analyze the changes in the traditional rice farming system in Sindang Hamlet of West Java, Indonesia and the role of green revolution and climate changes in such changes.

\section{MATERIALS AND METHODS}

\section{Study site}

This study was conducted in Sindang Hamlet, Rancakalong Village, Sumedang District, West Java Province, Indonesia (Figure 1). Rancakalong Village, located at latitude $6^{\circ} 50^{\prime} 082.2$ "S-107 $50^{\prime} 12.6 \mathrm{E}$, has an altitude of $700 \mathrm{~m}$ above sea level, the average annual rainfall is $1500-3000 \mathrm{~mm}$, while the average temperature is $22^{\circ}$. Sindang Hamlet has 598 houses holds in 2019 (Profile of Rancakalong Village 2019). This research was conducted only on Sindang Hamlet, which was previously known to have the largest number of farmers growing local rice and also high diversity of local rice totaling 22 cultivars (Warsiti 2009). Crops commonly planted in the study hamlet are rice, hui Cilembu (sweet potato Cilembu), corn, tobacco and vegetables such as cabbage, chilli, and tomato. There are 2 types of rice fields in Rancakalong village, namely ledok rice field (high water level) and cengkar rice field (medium water level).

\section{Procedure}

The qualitative method used in this study uses an ethnoecological approach with emphasis on the changes in the process of paddy field management systems (Newing et al. 2011; Albuquerque et al. 2014; Iskandar and Iskandar 2016; Iskandar 2018). Field data are collected by observations and semi-structured deep-interviews. The observation method was used to observe general ecological conditions of the agroecosystem types, including the wet rice field (sawah) systems. Semi-structured interviews (deep interviews) were carried out with 15 informants who were considered competent and knowledgeable related to changes in rice management systems in Sindang Hamlet. The informants were chosen purposively in accordance with their respective expertise, included farmers who planted local rice, superior (high yielding) rice and both of these cultivars; village leaders and their staff, informal leaders (sesepuh), agricultural ceremony experts (dukun or punuh), and members of rurukan (traditional arts groups). Deep interviews were carried out using interview guidelines that had been prepared previously related to changes in the paddy management system in Sindang Hamlet. In addition, researchers also participated in the rice management activities and also a ritual of agricultural management in Rancakalong, named ngalaksa. 

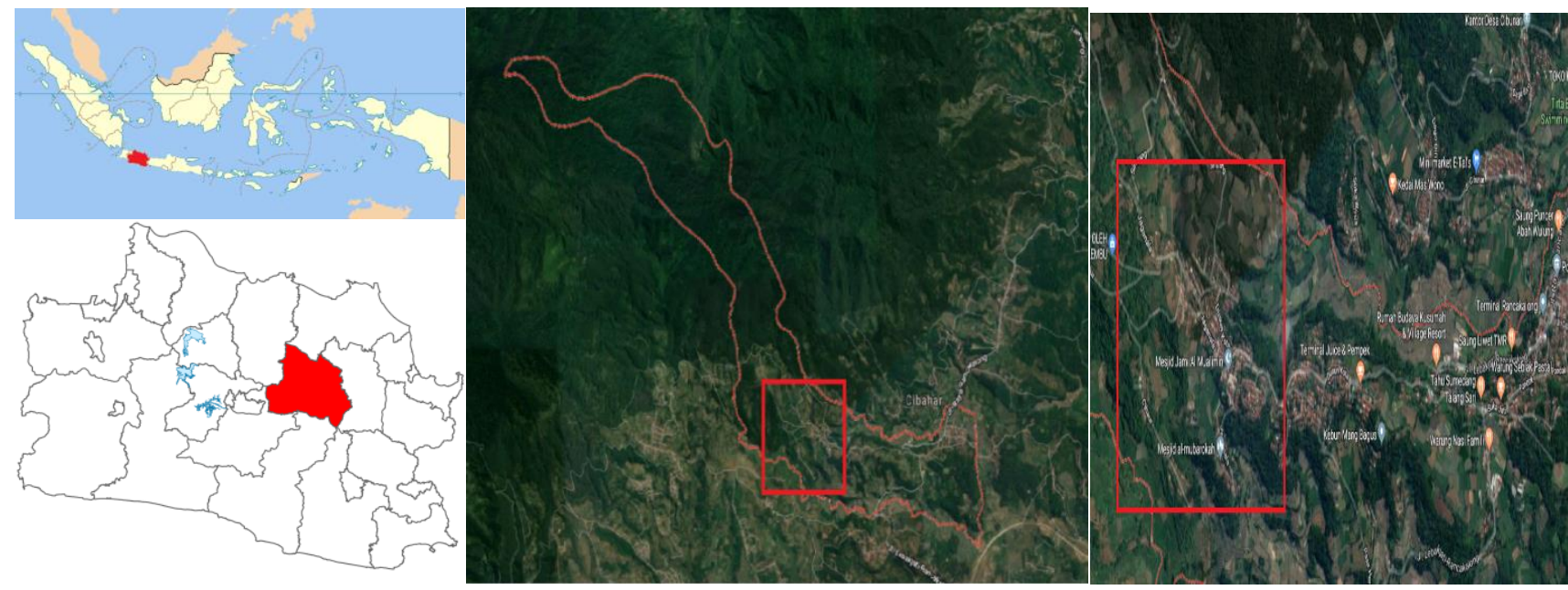

Figure 1. Location of study-Sindang Hamlet, Rancakalong Village, Sumedang District, West Java, Indonesia

\section{Data analysis}

Data analysis was carried out by cross-checking, summarizing and synthesizing several types of data, namely the results of semi-structured interviews, participatory observations and secondary data, which were then made into a descriptive narrative containing changes in rice management including the local rice cultivars still planted today, how farmers carry out paddy management and rituals related to agricultural management. After knowing the changes, an analysis of the impact of changes in ecological, economic and social aspects was carried out.

\section{RESULTS AND DISCUSSION}

\section{Local rice cultivars}

Indonesia has two main types of rice, javanica, and indica. Javanica is a local rice variety that was found growing in Indonesia long before the indica group (Rachmawati et al. 2004). Javanica is found only on the island of Java, with the characteristics of the relatively long age, wide leaves, tall thatch and seeds that do not fall off easily (Siregar 1981; Iskandar 2001). Before planting, farmers usually choose various rice seeds to be planted. Seed selection is based primarily on the quality of each rice variety from the previous crop, if possible from the same plot. Rice seeds are prepared as early as possible after the new harvest. Exchange and borrowing of seeds among farmers, relatives or neighbors are common. Women play an important role in the selection of traditional rice seeds. This is due to the worship of farmers of the rice goddess, Nyai Pohaci or Nyi Pohaci (Sunda) or Dewi Sri (Java) (Wessing 1978; Iskandar and Iskandar 2011).

Before the green revolution, the whole community planted local rice cultivars (pare jangkung/pare buhun) in wet-paddy fields (sawah) and dry land (huma). After the green revolution, the government recommended planting high-yielding rice cultivars (superior rice/pare pendek/pare enggal). Many farmers in Sindang Hamlet began trying to plant superior rice around the 1990s. Superior rice cultivars can be harvested every 6 months, longer period than a local rice cultivar that can be harvested in just 4 months. According to local knowledge, these two rice cultivars can be distinguished from several characteristics. Among the places, local rice is more suitable to higher places, which has a canopy of trees, but will continue to grow both in cengkar and ledok rice fields. Local rice cultivars (pare buhun) consist of two types, namely pare ranggeuy (hanging) whose ears do not fall off easily and pare sengon whose ears fall off easily. In addition, local rice usually has a higher plant size $( \pm 1.3 \mathrm{~m})$ than superior rice $( \pm 70 \mathrm{~cm})$. The number of local rice seedlings that are usually planted in one hole is around 2-3 but will grow to around 10 stems while superior rice is around 5-6 pieces and will develop according to the numbers planted.

According to Warsiti (2009), there were 22 local rice cultivars in Sindang Hamlet, Rancakalong Village, after green revolution. This is far less than the number of local rice cultivars recorded before the green revolution, which was about 60 cultivars (Malia 2007). This number is also small when compared to the local rice diversity that existed with the 46 cultivators of Kasepuhan, Sinaresmi (Soemarwoto 2007), Baduy Dalam and Baduy Luar (89 cultivars, Iskandar 1999), and in the Upper Citarum Watershed before the green revolution (88 cultivars, Parikesit et al. 1997). At present, only 6 local rice cultivars are planted in Sindang Hamlet, which are called rayot, mesir, omas, torondol, mataram and randa kaya.

Local rice is divided into several groups namely pare segon, pare ranggeuyan and sticky rice ranggeuy. Some of the cultivars belonging to the segon group include bengawan, gombot, torondol, omas, and mesir. The pare ranggeuyan group includes mataram, racik, gadog hawara, hawara tamiang, etc. Meanwhile, sticky rice consists of sari kuning, randa kaya, and Silver Sticky Rice. In the past, all of farmers in Sindang Hamlet planted local rice in their land. After the influence of the green revolution, around the 1990s, they began trying to plant superior rice. Some of 
them choose to switch, while others choose to continue growing local rice. Result of the study showed that there are 3 groups of farmers in Sindang Hamlet which are farmers who plant local rice cultivars, farmers who plant superior rice cultivars, and farmers who plant local rice cultivars and superior rice cultivars in their land. We have noted that the farmers in this study grow mostly local rice. The reason for their preference for local rice is because it has fluffy taste (pulen). Local rice also has lower maintenance costs because they didn't use pesticides and they also fetch higher prices compared to superior rice. Local rice is usually sold at Rp. 5,500-Rp. 7000/kg, while the superior rice is Rp. 5,000-Rp. 6,000/kg.

The diversity of local rice decreased because of the entry of superior rice, which forced farmers to try new types and leave many local rice cultivars that already existed. The community also made an effort to keep growing local rice. If their land is adjacent to superior paddy fields, birds will attack local rice, because usually superior paddy fields are more susceptible to pests than local rice and often monitored by farmers. Some farmers organized them into a group to plant local rice in the entire area. One such group is Sari Mukti farmer group in Pasirbiru Village, a village bordering Rancakalong Village. This farmer group consisted of 20 farmers from the villages of Rancakalong and Pasirbiru who planted local rice on all adjacent rice fields in the Ciherang Hamlet area, Pasirbiru Village. The existence of such farmer groups makes it easy for the community to work together to manage locally grown rice cultivars.

\section{Paddy management system}

The process of managing paddy fields in Sindang Hamlet may be divided into the period before planting, planting period and maintenance period, until the harvest time.
Table 1 provides a comparison of paddy field management before and after green revolution in Sindang hamlet. Farmers in Sindang Hamlet are aware of the traditional calendar or calculation of determining the dry and rainy seasons, called Parhetangan., In another place of Java it is usually called Pranata Mangsa or Pranoto Mangso. The calculation determines in which month the community must begin planting and harvesting rice based on natural signs related to rainy and dry seasons. This is also related to timimg of each part of rice management, such as determining when to plant, fertilize and harvest rice each month. The 1 st day of each month is called 'in accordance with root' (ninggang di akar), the 2nd is called the ninggang di tangkal (stem), the $3 \mathrm{rd}$ is called the ninggang di daun (leaves), and the 4th is called the ninggang di biji (seed).

Ninggang in Sundanese means to overwrite, meaning that each date reflects the best development of rice plants. Planting is best done on the $1^{\text {st }}$ day, when the rice plants overwrite in the roots. On the 2nd day is the best time for farmers to provide pesticides (ngalandongan). Meanwhile, the best time for harvest is the 4th day of the month. Farmers also have knowledge that in the fifth month of May (Rowah Month), there will be many pests, so they avoid harvesting in that month. Farmers usually plant rice early so they can be harvested before May. Now, after green revolution farmers in Sindang Hamlet do not use 'traditional calculation' (parhetangan) to determine the time of dry and rainy season, because there is usually a mismatch between predictions and reality. The rice field irrigation that is carried out in the Sindang Hamlet is of two types, there are rice fields that are irrigated while some of them are rain fed. Meanwhile, before the green revolution, all rice fields were rain fed and were very much dependent on the rainy seasons. The availability of water throughout the year affects the community's growing patterns without a period of fallow (rest) of the land.

Table 1. Differences between management of rice paddy field before and after green revolution

\begin{tabular}{|c|c|c|}
\hline Rice stages management & $\begin{array}{l}\text { Agricultural management before the green } \\
\text { revolution }\end{array}$ & $\begin{array}{l}\text { Agricultural management after the green } \\
\text { revolution }\end{array}$ \\
\hline Rice cultivars & Local rice cultivar & $\begin{array}{l}\text { Local rice, superior rice, local rice and } \\
\text { Superior Rice cultivar }\end{array}$ \\
\hline $\begin{array}{l}\text { Determination of planting and } \\
\text { harvesting time }\end{array}$ & Use parhetangan & The use of parhetangan has decreased \\
\hline Preparation of irrigation channels & Done with family and relatives (liliuran) & Hired workers \\
\hline Seed Selection & $\begin{array}{l}\text { Seeds are obtained from borrowing or } \\
\text { exchanging with relatives and previous harvests }\end{array}$ & from the previous crop \\
\hline Nursery & $\begin{array}{l}\text { Soaking (dikeueum) and kept in in the closed } \\
\text { place after soaking, waiting to germinate } \\
\text { (dituuskeun) }\end{array}$ & $\begin{array}{l}\text { Soaking (dikeueum) and kept in in the closed } \\
\text { place after soaking, waiting to germinate } \\
\text { (dituuskeun) }\end{array}$ \\
\hline Land management & Plowing the fields by hoeing or using cattle & Plowing the fields using tractors (talektor) \\
\hline Planting (tandur) & Distance of seedling $27 \times 27 \mathrm{~cm}$ or $33 \times 33 \mathrm{~cm}$ & Distance of seedling $27 \times 27 \mathrm{~cm}^{2}$ or $33 \times 33 \mathrm{~cm}^{2}$ \\
\hline Fertilization & Using natural fertilizers and pesticides & Use synthetic fertilizers \\
\hline Weeding (ngarambet) & Manual & Use tool like a fork (gasrok) \\
\hline Harvesting & $\begin{array}{l}\text { Use small hand knife for harvesting rice } \\
\text { (etem/ani-ani) }\end{array}$ & Use sickle (arit) \\
\hline
\end{tabular}


Everyone could grow the crop of their choice. Availability of rice plants most of the time in a year increases the likelihood of attack by pests, which keep moving from one field to another. The rice fields in Sindang Hamlet are drained by springs from Ciherang. Meanwhile, the whole land in Rancakalong Village is drained by the Ciherang and Cipungkur Rivers, which are the boundaries of Rancakalong Village. Farmers, before the green revolution, used to make liliuran or work together with their family and relatives to prepare waterways. But, after the green revolution, farmers in Sindang Hamlet prepare irrigation by hiring workers than do liliuran.

The seeds used by farmers were the result of selection from previous harvests. Women usually make the selection of seeds that have the criteria that farmers want, for example, long panicles, uniform grain size, etc. These seeds were soaked (dikeeum) for one night. Then, the seeds stored in a large bowl covered with cloth for 5 days (dituuskeun), until the accrual is out. The seeds are then spread in paddy field of $1 \times 1 \mathrm{~m}^{2}$ on the edge of the fields for germination, seedlings were allowed to grow for 25 to 30 days for planting. There are no significant changes before and after green revolution in the seed selection and seedbed process. The community continues to follow almost the same, even though the rice cultivars planted have changed from local rice to superior rice.

Land preparation is done by plowing the fields. Before the green revolution, the farmers cultivated rice fields using hoes and then plowed with the help of cattle. However, after the green revolution, most farmers in Sindang Hamlet are using tractors, while only those having small areas of land are using hoes. Using tractor makes a small number of chunks of land and leveling the soil making it easier to be planted again, especially, if after planting rice, they plan to plant hui Cileumbu, compared to using hoes or cattle.

Regarding planting procedure (tandur), rice seedlings are planted with a distance of $27 \times 27 \mathrm{~cm}^{2}$ or $30 \times 30 \mathrm{~cm}^{2}$. Before the green revolution, fertilizers were given in the form of mixed fertilizers, prepared from food scraps mixed with moles (coconut water/rice water/sugar water) fermented for 15 days, and dung or goat droppings, which were sometimes mixed with kirinyuh leaves (Chromolaena odorata). In addition, farmers also used natural pesticides such as a mixture of berenuk (Crescentia cujete) and detergents, a solution of koneng gede (turmeric), panglai (Zingiber cassumunar) mixed with water for pests of local rice. The community was aware that planting using natural fertilizers or pesticides makes rice stronger. When stored for a long time, the rice gets hardened and becomes striped (black and white). But, superior rice grown using synthetic pesticides does not last long. If stored for more than 2 weeks, the rice turns into flour. Now, farmers who grow local rice, usually use synthetic fertilizers for their land but do not use pesticides. Before harvesting, they spray organic pesticides such as a solution of water and koneng gede (turmeric) because they believed turmeric odor would repel pest attacks. But farmers who planted superior rice, use synthetic fertilizers and pesticides.
Besides applying fertilizers and repelling pests, farmers clean the weeds that block the growth of rice. Before the green revolution, they used manual methods to pull out weeds. After the green revolution, farmers used gasrok (rakes) to weed rice (ngarambet). Ngarambet is done twice in one planting period. Rice that is ready is harvested using sickles. In the past, because all of inhabitants of Sindang Hamlet planted local rice, harvesting was done using small hand knife (etem). Before the green revolution, the paddy was knocked down by being beaten (paddled), while now farmers in Sindang Hamlet are using hullers.

\section{Rituals related to agricultural management}

In the rice agricultural management, the farmers of Sindang Hamlet, Rancakalong Village observe number of rituals that are still being performed (Figures 2-3). Among such rituals included are tawasulan (thanksgiving) before land management (macul), before harvesting (nyalin) and biggest harvesting ceremony called ngalaksa. Before harvesting, in the traditional ritual of nyalin, the community still uses various kinds of salad (rujak) placed in a small wood house (saung) called rurujakan which is a sign of the harvest from the rice fields. Rurujakan contains a variety of offerings, including tamarind salad (rujak asem), coconut salad (rujak kalapa), banana salad (rujak cau), covered with kawung leaves (Arenga piñata).

Ngalaksa is a traditional event in Rancakalong District, commemorating the harvest as a form of gratitude. Ngalaksa is derived from the word "laksa" which means 'it is done'. This is gratitude for the harvest that has been carried out and hopes that all the wishes of the community in the future are fulfilled. Laksa also has the meaning of a kind of food that is derived from rice flour and is wrapped in congkok leaves (Curculigo orchioides). Laksa is boiled using combrang leaves (Etlingera elatior) which are believed to make it long-lasting. Tarawangsa which is an art of music using flute and fiddle is played during the ceremony. Ngalaksa traditional ceremony is held around the $7^{\text {th }}$ month (July), for 7 days and 7 nights. Determination of the time and preparation for the execution of ngalaksa is carried out by a rurukan. Rurukan is a group of artists in each village which has a senior elder who has been carrying out ngalaksa (Figure 4).

Five villages in the organizing committee are Rancakalong Village, Nagarawangi Village, Pasirbiru Village, Pamekaran Village and Cibunar Village, each village organizing the ritual in a year. Meanwhile, residents from 5 other villages in Rancakalong District usually participate in enlivening the event as spectators or performing artists. Before the green revolution, the people organized and participated in ngalaksa by moving from one village to another. However, since its inauguration in 2005 , the event is being held in a special traditional building (desa wisata) located in Rancakalong Hamlet, Rancakalong Village, which is managed by the Culture and Tourism Department. 


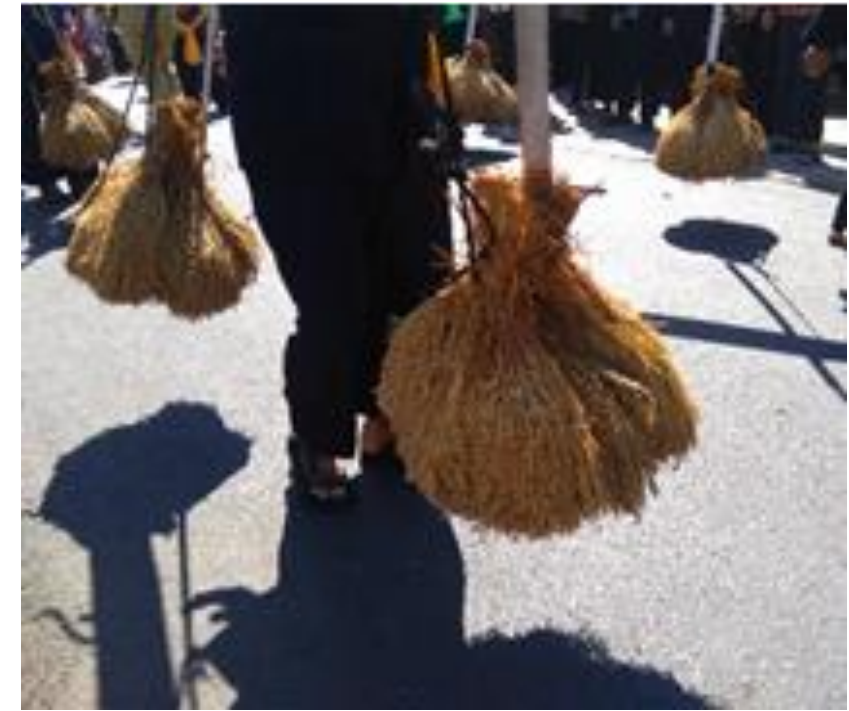

Figure 2. Local rice (pare buhun/pare jangkung) is being carried for performing a ritual.

During the ngalaksa ceremony, the community collects food ingredients in the form of rice (earlier, used to be local rice cultivar only, now it is mixed with superior rice cultivar). Local rice variety is still used for the opening ceremony, because the ears do not easily fall out and are still hanging (ranggeuy). This ensures that local rice has its own aesthetics when hung and paraded using rengkong (large bamboo stems). Pare buhun is still maintained as the main ingredient of laksa. Every citizen usually takes $3-5 \mathrm{~kg}$ bunch of rice (saundan/sapocong), along with other foods such as chicken and banana (cau). Food from the community is usually accommodated first. Before the green revolution, only local rice was used in ngalaksa. Meanwhile, after the green revolution, its mixed with superior rice.

Previously, the purpose of ngalaksa was to meet the food needs of all residents, so that all food ingredients were gathered together to make traditional cake. At that time the implementation of ngalaksa was centered in the forest of Cibunar Village called panglaksaan. There is a watering center and a source of laksa leaves. Now the ngalaksa traditional ceremony is in the district agenda which continues to be held every month. This also influences the time of its organization, which is decided by negotiation among the members of the jury, even though the time set for organizing the event must be suitable to the local government agenda, as well as the availability of funds from the government.

In 2019, Nagarawangi Village was on the ngalaksa implementation committee. The event procession began on July 16, 2019 with consideration of the harvest. The stages of ngalaksa implementation consist of:

\section{Bewara}

Notification of the implementation of ngalaksa. This stage includes the opening, the Regent's procession on the first day.

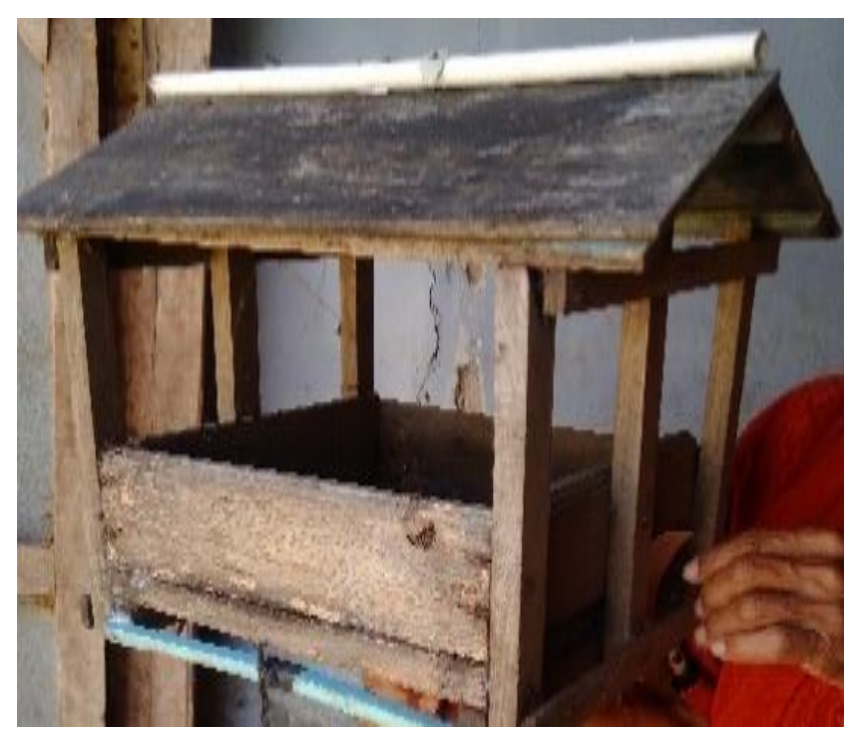

Figure 3. Saung is a place for placing salads in nyalin ceremony

\section{Ngayun/ngantosan}

Waiting for all the ingredients from the community for the ngalaksa ceremony to be collected. This stage is also carried out on the first day. The materials are collected at ngalaksa's place.

\section{Mera/tarawangsa}

On the second day, the committee arranges the materials. They also make preparations for laksa, by soaking in combrang (Etlingera elatior).

\section{Principal}

The ngalaksa core program lasting for one week, accompanied by tarawangsa music.

\section{Ecological, economic and social impacts}

Changes in the management of rice fields in Sindang Hamlet, resulting in various impacts. This is mainly due to the change in the source and nature of inputs that were previously natural and environmentally friendly, to synthetic along with the use of modern technology which require more energy. Before the green revolution, all of Sindang Hamlet farmers planted local rice, using natural fertilizers and pesticides made by themselves. At present, there are farmers who still continue this practice, but their numbers are outdone by the farmers who use fertilizers and pesticides purchased from village cooperatives. The continuous use of synthetic pesticides and fertilizers with increasing dosages will have a negative impact on the environment, especially on soil fertility, water conditions and surrounding animals.

In terms of ecology, the excessive use of urea is felt by the community to influence soil conditions. The longer the use, soil turns drier. This also tempts the community to use more water. 


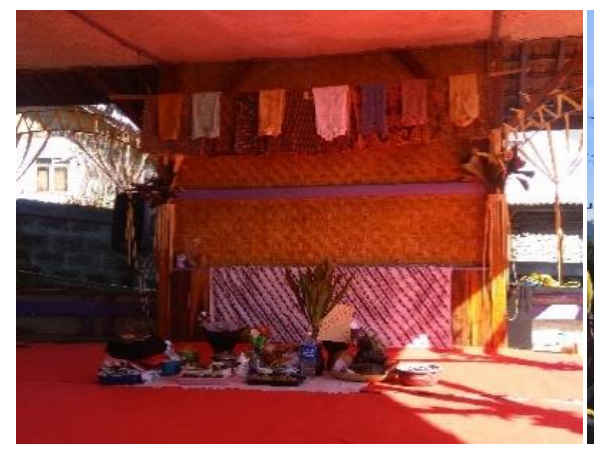

$\mathbf{A}$

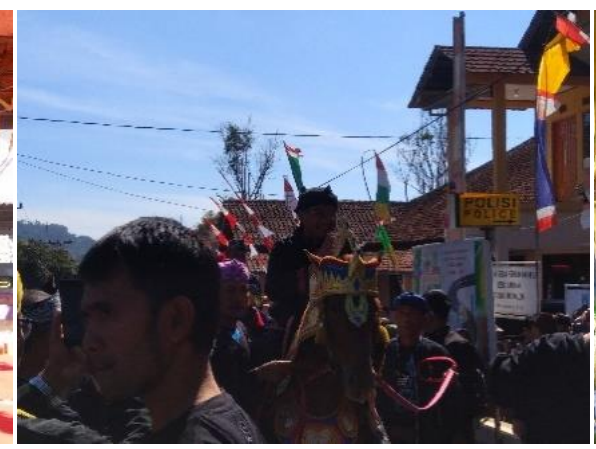

B

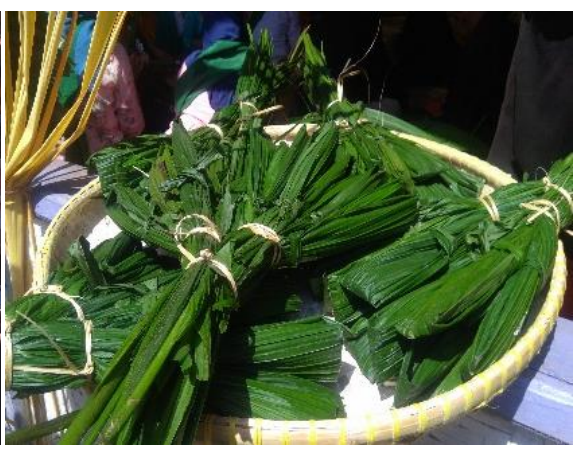

C

Figure 4. A. Offerings and place to play tarawangsa, B. A view of ngalaksa, C. Laksa (food from pounded rice)

Apart from the use of pesticides, non-simultaneous planting also leads to continued survival of pests, making eradication of pests difficult or pests become resistant to pesticides. According to Prabowo and Subantoro (2012), the excessive use of pesticides will cause a decrease in the quality of water used by the community due to excessive contamination by pesticides from agricultural land. Pesticides that are used for pest control, ideally have to kill only target organisms like brown planthopper. But in fact, other organisms and humans are also affected by pesticides. The animals that live in rice fields such as eels and worms have become rare to find because of the toxic water. Farmers also feel the painful and itchy effect when spraying pesticides without gloves.

Economically, the change in local rice cultivation to superior rice is beneficial in terms of increase in the number of harvests possible in one year which can reach up to 3 , while only 2 harvests can be done with local rice. However, in terms of inputs, farmers must spend fertilizer capital of Rp. 125,000 for every 100 bata of land (1 bata $=$ $7 \times 7 \mathrm{~m}$ ). Meanwhile, if natural fertilizers and pesticides are used, this capital input can be saved. From a social perspective, there are actually no differences that are too significant in terms of mutual cooperation (liliuran). If a farmer lives close to his siblings, then mutual cooperation in the fields are still carried out. However, this culture is starting to fade away in the younger generation. In addition, with a planting system that relinquishes fully to landowners, farmers with large land area produce more than small farmers. This, of course, increasing social inequality in society.

\section{ACKNOWLEDGEMENTS}

The research was funded through the University Padjadjaran Lecturer Competency Research Grant, and is part of a research program of Dr. Ruhyat Partasasmita with the theme "The Role of Ethno-Ecology Agroecosystem in Supporting Food Security and Health in Traditional Sundanese Communities: case studies in Baduy, Ciptagelar and Rancakalong communities". Authors are thankful to the Rector of the University of Padjadjaran who has programmed RKDU (University Padjadjaran Lecturer Competency Research Grant). Thanks are also due to all those who contributed to this study, especially the local people of Sindang Hamlet of Rancakalong Village for the information provided.

\section{REFERENCES}

Albuquerque UP, Ramos MA, de Lucena RFP, Alencar NL. 2014. Methods and techniques used to collect ethnobiological data. In Albuquerque UP, Cruz da Cunha LF, Paiva de Lucena RF, Alves RRN (eds), Methods and Techniques in Ethnobiology and Ethnoecology. Springer Science+ Business Media, New York.

Amelia F, Iskandar J, Partasasmita R, Malone N. 2018. Recognizing indigenous knowledge of the Karangwangi Rural Landscape in South Cianjur, Indonesia for sustainable land management. Biodiversitas 19: $1722-1729$

Berkes F. 1999. Sacred ecology: traditional ecological knowledge and resource management. Taylor and Francis, Philadelphia.

Berkes F. 2008. Sacred Ecology. Second Edition. Routledge, New York.

Fox JJ. 1991. Managing the ecology of rice production in Indonesia. In Hardjono J. (ed), Indonesia: Resources, Ecology, and Environment. Oxford University Press, Oxford New York.

Iskandar J, Ellen RF. 1999. In situ conservation of rice landraces among the Baduy of West Java. J Ethnobiol 19 (1): 97-125

Iskandar J. 2001. Human culture and environment: human ecology. Humaniora Utama Press. Bandung. [Indonesian]

Iskandar J, Iskandar BS. 2011. Sundanese Agroecosystem. PT Kiblat Buku Utama, Bandung. [Indonesian]

Iskandar J. 2012. Ethnobiology and Sustainable Development. Puslitbang KPK LPPM Unpad Bandung, M63 Foundation, AIPI, Bandung. [Indonesian]

Iskandar J. 2016. Ethnobiology and diversity of Indonesian culture. Umbara, Bandung. [Indonesian]

Iskandar J. 2018. Ethnobiology, Ethnoecology, and Sustainable Development. Plantaxia, Yogyakarta. [Indonesian].

Iskandar J, Iskandar BS. 2016. Ethnoastronomy the baduy agricultural calendar and prediction of environmental perturbation. Biodiversitas 17 (2): 694-703.

Iskandar J, Iskandar BS. 2017. Local knowledge of Baduy community of South Banten (Indonesia) on the traditional landscapes. Biodiversitas 18: $928-938$.

Iskandar J. 2018. Ethnobiology, ethnoecology and sustainable development. Plantaxia, Yogyakarta. [Indonesian]

Kadarisno. 2019. Analysis of Sawah Farmers Business Sustainability in Kampung Kuta, Tasikmalaya, West Java. [Thesis]. Program Masters in Environmental Sciences,. Universitas Padjadajaran, Sumedang. [Indonesian]

Lauer RH. 2003. Perspectives on Social Change. Rineka Cipta, Jakarta. [Indonesian] 
Lansing JS. 1991. Priests and Programmers: Technologies of Power in the Engineered Landscape of Bali. Princeton University Press, Princeton, New Jersey.

Malia. 2007. Study of Utilization and Management of Local Rice Cultivars in Rancakalong Village, Rancakalong District, Sumedang District [Hon. Thesis]. Universitas Padjadjaran, Sumedang. [Indonesian]

Mustapa RHH. 1996. Sundanese Customs. Penerbit Alumni, Bandung. [Indonesian]

Newing H, Eagle CM, Puri RK, Watson CW. 2011. Conducting Research in Conservation: a Social Science Perspective. Routledge, London.

Parkesit, Djuniwarti, Hadikusumah HY. 1997. Spatial structure and floristic diversity of man-made ecosystem in upper Citarum river basin. In Dove MR, Sajise P. (eds). The Conditions of Biodiversity Maintenance in Asia. East-West Center, Hawaii.

Partasasmita R, Hidayat RA, Erawan TS, Iskandar J. 2016. Loca knowledge of Karangwangi village people's, Cianjur District abou variation (race), the keeping activity and conservation of chicken (Gallus gallus domesticus Linnaeus, 1758). Pros Sem Nas Masy Biodiv Indon 2: 113-119. [Indonesian]

Partasmita R, Iskandar BS, Nuraeni S, Iskandar J. 2019. Impact of the green revolution on the gender's role in wet rice farming: A case study in Karangwangi Village, Cianjur District, West Java, Indonesia. Biodiversitas 20: 23-36.

Prabowo R, Subantoro R. 2012.Water quality and the burden of pesticide pollution in the Semarang City Babon River. J Ilmu Pertanian. 8 (1): 9-17. [Indonesian]
Profile of Rancakalong Village. 2019. Village Government of Rancakalong, Sumedang. [Indonesian]

Rachmawati D, Hosaka T, Inoue E, Anzai H. 2004. Agrobacteriummediated. 2004. Transformation of Javanica Rice cv. Rojolele. Gene Research Center, Ibaraki University, Jepang and Fakultas Biologi, Universitas Gadjah Mada, Yogyakarta.

Soemarwoto R. 2007. Kesepuhan rice landrace diversity, risk management and agricultural modernization. In: Ellen R. (ed), Modern crises and traditional strategies: local ecological knowledge in Island Southeast Asia. Berghahn Books, New York.

Toledo VM. 2002. Ethnoecology: A conceptual framework for the study of indigenous knowledge of nature. In: Stepp JR, Wyndham FS, Zarger RK. (eds). Ethnobiology and Biocultural. The International Society of Ethnobiology, Georgia

Warsiti I. 2009. Management and Utilization of Local Rice Cultivars and Factors Affecting the Sustainability of Local Rice Cultivars. Thesis: Study Program Masters in Environmental Science, Padjadjaran University, Bandung. [Indonesian]

Widjaja EA, Rhayuningsih Y, Rahajoe JS, Ubaidillah R, Maryanto I, Waluyo EB, Semiadi G. 2014. The present of Indonesia's biodiversity 2014. LIPI Press, Jakarta. [Indonesian]

Winarto, Yunita T. 2016. The food crisis and the "misguided thinking" why it still continues? Yayasan Pustaka Obor Indonesia, Jakarta. [Indonesian] 